\title{
Residual effect of commonly used herbicides of sugarcane on pre-emergence of peanut cultivars in succession
}

\section{Henrique Gonzalez Zanardo ${ }^{1}$, Willians César Carrega*1, Allan Lopes Bacha ${ }^{1}$, Pedro de Figueiredo Rocha Barbosa Martins ${ }^{1}$, Anne Elise Cesarin ${ }^{1}$, Pedro Luis da Costa Aguiar Alves ${ }^{1}$, Ignácio José de Godoy²}

\author{
${ }^{1}$ Department of Crop Production, FCAV/Unesp, Jaboticabal, São Paulo, Brazil \\ ${ }^{2}$ Grain and Fiber Center, Agronomic Institute of Campinas (IAC), São Paulo, Brazil
}

*Corresponding author: willianscesar@hotmail.com

\begin{abstract}
Studies on the residual effect of herbicides commonly used in sugarcane on peanut crops are essential for crop management due to the expansion of peanut areas on sugarcane fields throughout the country. Therefore, this work evaluates the effect of herbicides commonly used in sugarcane crops on the pre-emergence of five peanut cultivars. The experimental design was a randomized block with treatments in factorial arrangement: 11 (10 herbicides +1 water control) x 5 (peanut genotypes) in four replications. To evaluate the residual effect, plants that normally emerged at 15 days after application (DAA) were counted and the visual evaluation of plant toxicity was performed at 16, 23 and 30 DAA. At the end of the experiment, dry matter of shoots and roots was measured. According to the results, line 870 and cultivar IAC 503 were tolerant to mesotrione $\left(0.144\right.$ a.i. ha $\left.{ }^{-1}\right)$ in the preemergence. However, herbicides sulfentrazone and clomazone caused strong visual symptoms of toxicity, impairing the emergence and development of all genotypes. The herbicides imazapic, 2,4-D, saflufenacil and S-metolachlor, in turn, caused mild visual symptoms of toxicity, but also impaired the emergence and development of all genotypes. Hexazinone, tebuthiuron and amicarbazone applied in pre-emergence caused the death of cultivars. Mesotrione was the only herbicide feasible to the cultivars studied. The genotypes do not react equally to certain products, thus, there is a need for further studies under field conditions to confirm the responses obtained in this study and verify whether the yield potential is affected.
\end{abstract}

Keywords: Arachis hypogaea L.; emergence; phytotoxicity; weed science; management.

Abbreviations: a.i._active ingredient; a.e._acid equivalent; L_liters; kg_kilograms; g_grams; mg_milligrams; lb_pounds; $\mathrm{pH} \_$potential of hydrogen; $\mathrm{CaCl}_{2}$ Calcium chloride; $\mathrm{dm}^{3}$ _ cubic decimeter; $\mathrm{Mg}$ _ magnesium; $\mathrm{K}$,_potassium; $\mathrm{P} \_$phosphorus; $\mathrm{Ca}$ calcium; BS_base saturation; H+Al_potential acidity; mmol_millimole; m_meters; ha_hectares; DAS_days after sowing; DAA_days after application; $\mathrm{CO}_{2}$ carbon dioxide; IAC_Agronomic Institute of Campinas.

\section{Introduction}

Peanut is amongst the main oleaginous crops in Brazil, ranking fourth in importance worldwide (Santos et al., 2012). According to CONAB (2018), the national peanut production has increased by $46 \%$ from 267.6 thousand tons in the 2005/2006 harvest to 512.9 thousand tons in the $2017 / 2018$ harvest. São Paulo State is the main producer accounting for $94 \%$ of the total production. This increase in production is a result of consistent genetic breeding, inclusion of creeping cultivars, changes in the planting system, technological innovation and the insertion of peanuts in sugarcane reform areas. In the last harvest (2017/18), the sugarcane reform area in São Paulo State was about 524,000 ha-1 (Unica, 2018). Out of these, 128,000 ha-1 were planted with peanut (CONAB, 2018).

The expansion of peanut crops in succession, especially those in sugarcane areas, is highlighted as the main factor for increased national production. Sugarcane-peanut succession is a feasible alternative for soil conservation; weed control (Marenco and Santos, 1999) and soil quality
(Balota et al., 2004) since rotation may increase soil $\mathrm{N}$ content due to the symbiotic association of peanut plants to Rhyzobium bacteria (Seddique and Bal, 1991).. The use of peanuts in these areas of sugarcane reform in São Paulo could be much higher considering that only $25 \%$ of the sugarcane area is used for peanuts, which means a great potential for expansion of crops in these areas. Among the main difficulties in the peanut sector, we highlight the interference of weed and crop coexistence. Interspecific competition may reduce yield by more than $80 \%$ depending on cultivar, infestation density, composition and soil fertility (Agostinho et al., 2006; Nepomuceno et al., 2007).

Besides the difficulty of weed control, another hindrance found by farmers is the lack of information about the effects of herbicides commonly used in sugarcane on succession crops, and the low availability of herbicides for peanuts registered in Brazil. There are five herbicides registered for peanut crops in the Ministry of Agriculture, Livestock and Supply (Ministério da Agricultura, Pecuária e Abastecimento 
- MAPA). Out of these, two (alachlor and trifluralin) are preplanting herbicides, two (bentazon and quizalofop-p-ethyl) are post-emergence herbicides, and one (imazapic) is a preand post-emergence herbicide. In contrast, there are more than 40 herbicides available for sugarcane in the market aimed at pre and post-emergence application (Agrofit, 2017).

Due to the scarcity of herbicides registered for peanuts and the constant use of the same mechanism of action, the herbicide weed resistance may occur (Zanardo et al., 2018). In the USA, there have been reports of species Amaranthus palmeri and Ambrosia artemisiifolia resistant to ALS enzyme inhibitor herbicides (Heap, 2018). According to Burke et al. (2007), a single A. palmeri plant per linear meter can cause reduction of up to $28 \%$ in peanut yield. Cases of herbicide weed resistance were recorded in several crops in Brazil, although there have not been reports for peanut crops (Zanardo et al., 2018). However, cases involving A. Palmeri, which is a resistant species occurring in the USA, have already been registered in Brazil in crops such as cotton, soybean and beans (Heap, 2018). To prevent the occurrence of resistant weeds and provide better management alternatives, increased availability of herbicides in peanut crop is of paramount importance. The inclusion of peanut as a Crop with Insufficient Phytosanitary Support (CIPS) (MAPA, 2015) arises the possibility of opening the portfolio of other crops to be used along with peanut (Zanardo et al., 2018).

Among the main herbicides used in sugarcane areas are: a) auxin herbicides, which may induce many physiological and biochemical effects at low concentrations similar to those caused by natural auxin from plants (IAA) (Mithila et al., 2011); b) triazolinone and pyrimidinedione groups, which block the protox enzyme resulting in protoporphyrinogen accumulation in the plastids (Shoup and Al-Khatib, 2004); c) imidazolinone herbicides, which inhibit acetolactate synthase (ALS) enzyme, a key enzyme in branched-chain amino acid biosynthesis, leucin, isoleucine and valine (Tan et al., 2005); d) triacetone and isoxazolidinone groups, which are inhibitors of carotenoid biosynthesis, important protector of chloroplast pigment (Armel et al., 2007); e) PSIIinhibitor herbicides, which block the electron flow between photosystems by linking them to quinone $B\left(Q_{B}\right)$ of $D 1$ protein of PSII (Ventrella et al., 2010). The residual effect of some of these herbicides can be harmful for the peanut crop. Thus, there is a need to evaluate the phytotoxicity caused by these products when applied in the preemergence and verify the damages they can cause in peanut plants to select the tolerant cultivars.

Facing the inclusion of peanuts as CIPS and the crop expansion in sugarcane areas, it is hypothesized that herbicides used in sugarcane may be a viable alternative for controlling weeds in highly infested areas. Moreover, knowledge about the residual effects of herbicides commonly used in sugarcane and their different mechanisms of action must be properly understood in order these herbicides can be used in peanuts without affecting growth, development and crop yield. Therefore, this study evaluates the effect of herbicides used in sugarcane on the preplanting of five peanut cultivars to determine phytotoxicity symptoms and analyze the emergence and development of plants.

\section{Results and Discussion}

\section{Emergence test}

The results of the interaction between herbicides and cultivars indicate 2,4-D, hexazinone, tebuthiuron and imazapic) affected the emergence of all cultivars when compared to the control plot (Table 1).

The products that reduced the emergence of IAC Tatu-ST were: tebuthiuron (18\%), imazapic $(27 \%)$, sulfentrazone (31\%), 2,4-D (41\%), hexazinone (42\%), amicarbazone (45\%), mesotrione (72\%) and clomazone (75\%). Regarding line 870 , only sulfentrazone, clomazone and mesotrione caused emergence similar to the control plot. The remaining herbicides caused reductions of $27 \%$ (hexazinone and amicarbazone), 49\% (2,4-D and imazapic) and $80 \%$ (saflufenacil and tebuthiuron) (Table 1).

All herbicides reduced the emergence of IAC 505 seedlings. Treatments with 2,4-D, sulfentrazone, hexazinone, clomazone, imazapic and S-metolachlor resulted in the most harmful effect on emergence, reducing it by $87 \%$. Treatments with amicarbazone, saflufenacil, mesotrione and tebuthiuron reduced the emergence by $26,54,66$ and $74 \%$, respectively (Table 1 ).

For cultivar IAC 503, three treatments with herbicides were similar to the control plot: sulfentrazone, mesotrione and amicarbazone. However, emergence was reduced by $28 \%$ with sulfentrazone and amicarbazone. The other herbicides also affected emergence: imazapic (45\%), tebuthiuron (66\%), 2,4-D (71\%), hexazinone and clomazone (83\%), saflufenacil and s-metolachlor (52\%).

The results for cultivar Granoleico were similar to those obtained for IAC 505, in which all treatments negatively affected emergence. The treatments that caused the highest reduction rates were 2,4-D, sulfentrazone, hexazinone, imazapic and amicarbazone, with $88 \%$. The remaining treatments caused harmful effects: mesotrione, saflufenacil, S-metolachlor (43\% reduction), clomazone (60\%) and tebuthiuron (71\%) (Table 1).

\section{Visual phytotoxicity}

There was interaction between cultivars and herbicides for evaluations performed at 16, 23 and 30 DAA (Tables 2, 3 and 4). Amicarbazone, hexazinone and tebuthiuron caused the most severe phytotoxicity symptoms and death of plants of all cultivars studied (Tables 3 and 4 ).

Cultivars IAC 505 and IAC 503 also showed similar herbicide effects. Sulfentrazone caused high level of phytotoxicity (6) at 16 DAA and, the symptoms evolved at the last evaluation becoming severe (7). The other treatments resulted in low phytotoxicity levels until the end of the experimental period (Table 2).

By analyzing the interaction between herbicides for each cultivar, sulfentrazone and clomazone caused similar responses of IAC Tatu-ST, line 870 and Granoleico during evaluations. At 16 DAA, sulfentrazone caused initial symptoms classified between 6 and 7 (high), and clomazone caused medium to moderate levels of phytotoxicity (5) (Table 2). These symptoms has increased during the experimental period and persisted up to the last evaluation at $30 \mathrm{DAA}$, thus ceasing plant growth. At the same period (30 DAA), the other herbicides (2,4-D, saflufenacil, S- 
Table 1. Split analysis of the interaction between cultivars and herbicides regarding the emergence percentage of genotypes evaluated up to 15 days after application.

\begin{tabular}{|c|c|c|c|c|c|c|}
\hline \multirow[b]{2}{*}{ Herbicide } & \multicolumn{5}{|c|}{ Genotype } & \multirow[b]{2}{*}{$\mathrm{F}$} \\
\hline & IAC Tatu-ST & $\begin{array}{l}\text { Line } \\
870\end{array}$ & IAC 505 & IAC 503 & Granoleico & \\
\hline $2,4-D$ & $43 \mathrm{Efa}$ & $47 \mathrm{Da}$ & $07 \mathrm{Db}$ & $12 \mathrm{CDb}$ & $07 \mathrm{Db}$ & $56.5^{* *}$ \\
\hline Sulfentrazone & 50 DEFb & 73 Aba & $07 \mathrm{Db}$ & $30 \mathrm{Abc}$ & $07 \mathrm{Db}$ & $114.5 * *$ \\
\hline Hexazinone & $42 \mathrm{Efb}$ & $62 \mathrm{Bca}$ & $07 \mathrm{Dc}$ & $07 \mathrm{Dc}$ & $07 \mathrm{Dc}$ & $91.6^{* *}$ \\
\hline Clomazone & $18 \mathrm{~Gb}$ & $73 \mathrm{ABa}$ & $07 \mathrm{Dc}$ & $7 \mathrm{Dc}$ & $23 \mathrm{BCb}$ & $105.7 * *$ \\
\hline Mesotrione & $20 \mathrm{Gc}$ & $83 \mathrm{Aa}$ & $17 \mathrm{CDc}$ & $38 \mathrm{Ab}$ & $33 \mathrm{Bb}$ & $98.7^{* *}$ \\
\hline Saflufenacil & 70 Aba & $17 \mathrm{Ec}$ & $23 \mathrm{Cb}$ & $20 \mathrm{BCC}$ & $33 \mathrm{Bb}$ & $65.6 * *$ \\
\hline Tebuthiuron & $60 \mathrm{BCDa}$ & $15 \mathrm{~Eb}$ & $13 \mathrm{CDb}$ & $14 \mathrm{CDb}$ & $17 \mathrm{CDb}$ & $57.0^{* *}$ \\
\hline Imazapic & $53 \mathrm{CDEa}$ & $43 \mathrm{Da}$ & $07 \mathrm{Dc}$ & $23 \mathrm{BCb}$ & $7 \mathrm{Dc}$ & $62.2^{* *}$ \\
\hline S-metolachlor & $63 \mathrm{ABCb}$ & $80 \mathrm{Aa}$ & $07 \mathrm{Dc}$ & $20 \mathrm{BCd}$ & $33 \mathrm{Bc}$ & $127.8^{* *}$ \\
\hline Amicarbazone & $40 \mathrm{Fb}$ & $52 \mathrm{Cda}$ & $37 \mathrm{Bb}$ & $30 \mathrm{Abb}$ & $7 \mathrm{Dc}$ & $38.5^{* *}$ \\
\hline Control & $73 \mathrm{Ab}$ & $85 \mathrm{Aa}$ & $50 \mathrm{Acd}$ & $42 \mathrm{Ad}$ & $58 \mathrm{Ac}$ & $42.4^{* *}$ \\
\hline$F$ & $46.08 * *$ & $86.27^{* *}$ & $29.96 * *$ & $19.93^{* *}$ & $40.16^{* *}$ & \\
\hline
\end{tabular}

Means followed by the same uppercase in the column and lowercase in the line do not differ at $5 \%$ probability by the Tukey Test. By the $\mathrm{F}$ test, $* *$ significant at $1 \%$ probability. $\mathrm{F}$ (cultivars $\mathrm{x}$ herbicides) $=33.87^{* *} ; \mathrm{CV}(\%)=14.09$.

Table 2. Split analysis of the interaction between cultivars and herbicides regarding phytotoxicity evaluated at 16 days after application.

\begin{tabular}{|c|c|c|c|c|c|c|}
\hline \multirow{2}{*}{ Herbicide } & \multicolumn{5}{|c|}{ Genotype } & \multirow{2}{*}{$\mathrm{F}$} \\
\hline & IAC Tatu-ST & Line 870 & IAC 505 & IAC 503 & Granoleico & \\
\hline $2,4-D$ & 1.7 DEb & $2.0 \mathrm{CDb}$ & 5.0 Aba & $1.7 \mathrm{Fb}$ & $3.2 \mathrm{Cb}$ & $12.7 * *$ \\
\hline Sulfentrazone & $7.2 \mathrm{Aa}$ & $7.0 \mathrm{Aa}$ & $6.0 \mathrm{Aa}$ & $6.0 \mathrm{BCa}$ & $6.0 \mathrm{Aa}$ & $2.5^{\mathrm{ns}}$ \\
\hline Hexazinone & $9.0 \mathrm{Aa}$ & $6.0 \mathrm{ABb}$ & $4.7 \mathrm{ABb}$ & $9.0 \mathrm{Aa}$ & $5.0 \mathrm{ABCb}$ & $28.7^{* *}$ \\
\hline Clomazone & $4.0 \mathrm{BCd}$ & 5.0 Bab & 4.7 ABab & 3.7 DEb & $5.7 \mathrm{Aa}$ & $4.1 * *$ \\
\hline Mesotrione & $5.0 \mathrm{Ba}$ & $1.7 \mathrm{CDbc}$ & $3.2 \mathrm{Bb}$ & 2.2 EFbc & $1.2 \mathrm{Dc}$ & $14.2^{* *}$ \\
\hline Saflufenacil & $3.0 \mathrm{CDa}$ & $2.7 \mathrm{CDa}$ & $3.2 \mathrm{Ba}$ & 3.7 DEa & 4.2 ABCa & $2.3^{\mathrm{ns}}$ \\
\hline Tebuthiuron & $8.7 \mathrm{Aa}$ & $7.0 \mathrm{Ab}$ & $5.0 \mathrm{ABC}$ & 4.7 BCDC & $6.0 \mathrm{Abc}$ & $17.2^{* *}$ \\
\hline Imazapic & 2.0 DEb & $2.0 \mathrm{CDb}$ & $3.7 \mathrm{Ba}$ & 1.7 Fb & 3.7 BCa & $6.5^{* *}$ \\
\hline S-metolachlor & $5.0 \mathrm{Ba}$ & $3.0 \mathrm{Cb}$ & 5.0 Aba & $4.2 \mathrm{CDab}$ & 3.7 BCab & $4.7^{* *}$ \\
\hline Amicarbazone & $7.5 \mathrm{Aa}$ & 6.2 ABab & $3.2 \mathrm{Bc}$ & $6.2 \mathrm{Bab}$ & $6.2 \mathrm{ABb}$ & $16.2^{* *}$ \\
\hline Control & $1.0 \mathrm{Ea}$ & $1.0 \mathrm{Da}$ & $1.0 \mathrm{Ca}$ & $1.0 \mathrm{Fa}$ & $1.0 \mathrm{Da}$ & $0.0^{\mathrm{ns}}$ \\
\hline $\mathrm{F}$ & $53.00 * *$ & $34.10 * *$ & $12.15^{* *}$ & $36.88^{* *}$ & $19.93^{* *}$ & ----- \\
\hline
\end{tabular}

Means followed by the same uppercase in the column and lowercase in the line do not differ at $5 \%$ probability by the Tukey Test. By the $\mathrm{F}$ test, $* *$ significant at $1 \%$ probability, $\mathrm{ns}=$ non-significant. $\mathrm{F}$ (cultivars $\mathrm{x}$ herbicides $)=9.85^{* *} ; \mathrm{CV}(\%)=18.58$.

Table 3. Split analysis of the the interaction between cultivars and herbicides regarding phytotoxicity evaluated at 23 days after application.

\begin{tabular}{|c|c|c|c|c|c|c|}
\hline \multirow{2}{*}{ Herbicide } & \multicolumn{5}{|c|}{ Genotype } & \multirow{2}{*}{$\mathrm{F}$} \\
\hline & IAC Tatu-ST & Line 870 & IAC 505 & IAC 503 & Granoleico & \\
\hline $2,4-D$ & $1.5 \mathrm{Dc}$ & 1.7 DEbc & $4.0 \mathrm{CDa}$ & $1.2 \mathrm{EFc}$ & $3.2 \mathrm{Cab}$ & $8.1^{* *}$ \\
\hline Sulfentrazone & 7.7 Aa & 7.2 ABab & $5.7 \mathrm{BCb}$ & 6.7 Cab & 7.0 Bab & $3.0^{*}$ \\
\hline Hexazinone & $9.0 \mathrm{Aa}$ & 8.7 Aba & $8.2 \mathrm{Aa}$ & $9.0 \mathrm{Aa}$ & $6.0 \mathrm{Bb}$ & $9.0 * *$ \\
\hline Clomazone & $5.2 \mathrm{Bab}$ & $4.7 \mathrm{Cb}$ & $4.2 \mathrm{Cb}$ & $3.7 \mathrm{Db}$ & $6.5 \mathrm{Ba}$ & $6.2^{* *}$ \\
\hline Mesotrione & 3.7 BCa & 1.2 Deb & 2.2 DEab & 2.2 DEFab & $1.0 \mathrm{Db}$ & $6.6 * *$ \\
\hline Saflufenacil & $2.5 \mathrm{CDa}$ & 2.2 DEa & $2.0 \mathrm{Ea}$ & 2.0 DEFa & $2.2 \mathrm{CDa}$ & $0.2^{\mathrm{ns}}$ \\
\hline Tebuthiuron & $9.0 \mathrm{Aa}$ & $9.0 \mathrm{Aa}$ & $7.2 \mathrm{ABb}$ & $7.0 \mathrm{BCb}$ & $9.0 \mathrm{Aa}$ & $5.9 * *$ \\
\hline Imazapic & $2.5 \mathrm{CDab}$ & 1.2 DEab & $1.0 \mathrm{~Eb}$ & $1.0 \mathrm{Fb}$ & $2.7 \mathrm{CDa}$ & $4.1^{* *}$ \\
\hline S-metolachlor & $2.5 \mathrm{CDb}$ & $3.0 \mathrm{CDb}$ & $4.7 \mathrm{Ca}$ & 3.0 DEb & $2.0 \mathrm{CDb}$ & $6.0 * *$ \\
\hline Amicarbazone & 9.0 Aab & $7.0 \mathrm{Bbc}$ & 8.7 Aa & $8.7 \mathrm{ABa}$ & $6.2 \mathrm{Bc}$ & $7.0 * *$ \\
\hline Control & $1.0 \mathrm{Da}$ & 1.0 Ea & $1.0 \mathrm{Ea}$ & $1.0 \mathrm{Fa}$ & $1.0 \mathrm{Da}$ & $0.0^{\mathrm{ns}}$ \\
\hline $\mathrm{F}$ & $55.29 * *$ & $56.18 * *$ & $54.81^{* *}$ & $54.81^{* *}$ & $42.53 * *$ & ---- \\
\hline
\end{tabular}


Table 4. Split analysis of the interaction between cultivars and herbicides regarding phytotoxicity evaluated at 30 days after application.

\begin{tabular}{|c|c|c|c|c|c|c|}
\hline \multirow[b]{2}{*}{ Herbicide } & \multicolumn{5}{|c|}{ Genotype } & \multirow[t]{2}{*}{$\mathrm{F}$} \\
\hline & $\begin{array}{c}\text { IAC } \\
\text { Tatu-ST }\end{array}$ & Line 870 & IAC 505 & IAC 503 & Granoleico & \\
\hline $2,4-D$ & $1.2 \mathrm{DEa}$ & $2.0 \mathrm{Ea}$ & 2.2 DEa & $1.7 \mathrm{CDa}$ & $2.0 \mathrm{Da}$ & $1.0 \mathrm{~ns}$ \\
\hline Sulfentrazone & $7.7 \mathrm{Aa}$ & $5.7 \mathrm{BCb}$ & $7.0 \mathrm{Bb}$ & 7.0 Bab & $6.0 \mathrm{Cb}$ & $5.7 * *$ \\
\hline Hexazinone & $9.0 \mathrm{Aa}$ & $9.0 \mathrm{Aa}$ & $9.0 \mathrm{Aa}$ & $9.0 \mathrm{Aa}$ & $9.0 \mathrm{Cb}$ & $23.0 * *$ \\
\hline Clomazone & $5.2 \mathrm{Ba}$ & $5.2 \mathrm{CDa}$ & 3.7 CDb & $3.2 \mathrm{Cb}$ & $6.5 \mathrm{BCa}$ & $10.8 * *$ \\
\hline Mesotrione & 3.7 BCa & $2.2 \mathrm{~Eb}$ & $1.7 \mathrm{~Eb}$ & $1.7 \mathrm{CDb}$ & $1.2 \mathrm{Db}$ & $6.7^{* *}$ \\
\hline Saflufenacil & $2.7 \mathrm{CDa}$ & $2.2 \mathrm{Ea}$ & 1.7 Ea & $2.2 \mathrm{CDa}$ & $2.0 \mathrm{Da}$ & $0.1^{\mathrm{ns}}$ \\
\hline Tebuthiuron & $9.0 \mathrm{Aa}$ & $9.0 \mathrm{Aa}$ & $9.0 \mathrm{Aa}$ & $9.0 \mathrm{Aa}$ & $9.0 \mathrm{Aa}$ & $0.0^{\mathrm{ns}}$ \\
\hline Imazapic & $3.0 \mathrm{Ca}$ & 2.0 Eab & $1.0 \mathrm{~Eb}$ & $1.0 \mathrm{Db}$ & 1.7 Dab & $4.9 * *$ \\
\hline S-metolachlor & 2.2 CDEbc & $4.0 \mathrm{Da}$ & $4.0 \mathrm{Ca}$ & 3.0 Cab & $1.0 \mathrm{Dc}$ & $11.0 * *$ \\
\hline Amicarbazone & $9.0 \mathrm{Aab}$ & $9.0 \mathrm{Bb}$ & $9.0 \mathrm{Aa}$ & $9.0 \mathrm{Aa}$ & $9.0 \mathrm{ABab}$ & $3.8 * *$ \\
\hline Control & $1.0 \mathrm{Ba}$ & $1.0 \mathrm{Ea}$ & $1.0 \mathrm{Ea}$ & $1.0 \mathrm{Da}$ & $1.0 \mathrm{Da}$ & $0.0^{\mathrm{ns}}$ \\
\hline $\mathrm{F}$ & $71.92 * *$ & $61.40 * *$ & $75.88 * *$ & $81.36 * *$ & $63.10 * *$ & ------- \\
\hline
\end{tabular}

Table 5. Split analysis of the the interaction between cultivars and herbicides regarding dry matter of shoots (g) of genotypes evaluated at 30 days after application.

\begin{tabular}{|c|c|c|c|c|c|c|}
\hline \multirow{2}{*}{ Herbicide } & \multicolumn{5}{|c|}{ Genotype } & \multirow[t]{2}{*}{$\mathrm{F}$} \\
\hline & IAC Tatu-ST & Line 870 & IAC 505 & IAC 503 & Granoleico & \\
\hline $2,4-D$ & $1.0 \mathrm{Aa}$ & $1.0 \mathrm{Aba}$ & $0.5 \mathrm{Cc}$ & $0.9 \mathrm{ABa}$ & $0.7 \mathrm{CDb}$ & $22.4 * *$ \\
\hline Sulfentrazone & $0.4 \mathrm{Cc}$ & $0.8 \mathrm{Cab}$ & $0.8 \mathrm{Aba}$ & 0.7 BCDab & $0.6 \mathrm{Dbc}$ & $9.2^{* *}$ \\
\hline Hexazinone & $0.0 \mathrm{Da}$ & 0.0 Da & $0.0 \mathrm{Da}$ & $0.0 \mathrm{Fa}$ & $0.0 \mathrm{Ea}$ & $0.0^{\text {ns }}$ \\
\hline Clomazone & $0.6 \mathrm{BCb}$ & $0.8 \mathrm{Cb}$ & $0.7 \mathrm{BCb}$ & 0.6 Deb & 1.0 Aba & $9.4 * *$ \\
\hline Mesotrione & 1.0 Aab & $1.1 \mathrm{Aa}$ & $0.6 \mathrm{Cc}$ & $0.9 \mathrm{ABCb}$ & 1.0 Abab & $17.5^{* *}$ \\
\hline Saflufenacil & $0.8 \mathrm{Bb}$ & $1.1 \mathrm{Aa}$ & $0.9 \mathrm{Abb}$ & $0.7 \mathrm{BCDb}$ & $0.7 \mathrm{BCDb}$ & $10.9 * *$ \\
\hline Tebuthiuron & 0.0 Da & 0.0 Da & $0.0 \mathrm{Da}$ & $0.0 \mathrm{Fa}$ & $0.0 \mathrm{Ea}$ & $0.0^{\text {ns }}$ \\
\hline Imazapic & $1.1 \mathrm{Aa}$ & $1.1 \mathrm{Aa}$ & $0.8 \mathrm{Abb}$ & $1.1 \mathrm{Aa}$ & $0.6 \mathrm{CDb}$ & $15.5^{* *}$ \\
\hline S-metolachlor & $0.6 \mathrm{Bab}$ & 0.8 BCab & 0.7 Bcab & 0.6 CDEb & $0.9 \mathrm{BCa}$ & $3.2^{*}$ \\
\hline Amicarbazone & 0.0 Da & 0.0 Da & $0.0 \mathrm{Da}$ & $0.0 \mathrm{Fa}$ & $0.0 \mathrm{Ea}$ & $0.0^{\text {ns }}$ \\
\hline Control & $1.1 \mathrm{Aa}$ & $1.2 \mathrm{Aa}$ & $1.0 \mathrm{Aa}$ & $1.0 \mathrm{Aa}$ & $1.2 \mathrm{Aa}$ & $1.5^{\mathrm{ns}}$ \\
\hline $\mathrm{F}$ & $76.50 * *$ & $89.50 * *$ & $54.96 * *$ & $57.25 * *$ & $69.90 * *$ & ------- \\
\hline
\end{tabular}

Table 6. Split analysis of the interaction between cultivars and herbicides regarding dry matter of roots (g) of genotypes evaluated at 30 days after application.

\begin{tabular}{|c|c|c|c|c|c|c|}
\hline \multirow{2}{*}{ Herbicide } & \multicolumn{5}{|c|}{ Genotype } & \multirow{2}{*}{$\mathrm{F}$} \\
\hline & Tatu-ST & Line 870 & IAC 505 & IAC 503 & Granoleico & \\
\hline $2,4-D$ & $1.4 \mathrm{Aa}$ & $0.9 \mathrm{Abb}$ & $0.5 \mathrm{Dc}$ & $1.2 \mathrm{Aa}$ & $0.7 \mathrm{Cc}$ & $46.0 * *$ \\
\hline Sulfentrazone & $0.4 \mathrm{~Eb}$ & $0.6 \mathrm{Ca}$ & $0.7 \mathrm{BCDa}$ & $0.7 \mathrm{Cda}$ & $0.4 \mathrm{Db}$ & $8.7^{* *}$ \\
\hline Hexazinone & $0.0 \mathrm{Fa}$ & $0.0 \mathrm{Da}$ & $0.0 \mathrm{Ea}$ & $0.0 \mathrm{Ea}$ & $0.0 \mathrm{Ea}$ & $0.0 \mathrm{~ns}$ \\
\hline Clomazone & $0.5 \mathrm{Deb}$ & $0.6 \mathrm{Cb}$ & $0.7 \mathrm{CDb}$ & $0.7 \mathrm{CDb}$ & $1.0 \mathrm{Aba}$ & $12.7 * *$ \\
\hline Mesotrione & $0.7 \mathrm{CDb}$ & $1.0 \mathrm{Aa}$ & $0.6 \mathrm{Db}$ & 1.0 Aba & $0.9 \mathrm{Aba}$ & $17.6 * *$ \\
\hline Saflufenacil & $0.9 \mathrm{Bca}$ & 0.7 Bcab & $0.9 \mathrm{Aba}$ & 0.9 Bcab & $0.7 \mathrm{Cb}$ & $3.6 * *$ \\
\hline Tebuthiuron & $0.0 \mathrm{Fa}$ & $0.0 \mathrm{Da}$ & $0.0 \mathrm{Ea}$ & $0.0 \mathrm{Ea}$ & $0.0 \mathrm{Ea}$ & $0.0 \mathrm{~ns}$ \\
\hline Imazapic & $1.5 \mathrm{Aa}$ & $0.9 \mathrm{ABb}$ & $0.9 \mathrm{Abb}$ & $1.0 \mathrm{Abb}$ & $0.6 \mathrm{CDC}$ & $38.7 * *$ \\
\hline S-metolachlor & $0.8 \mathrm{Cab}$ & $0.6 \mathrm{Cb}$ & $0.7 \mathrm{Cdab}$ & $0.6 \mathrm{Dab}$ & $0.8 \mathrm{Bca}$ & $3.1^{*}$ \\
\hline Amicarbazone & $0.0 \mathrm{Fa}$ & $0.0 \mathrm{Da}$ & $0.0 \mathrm{Ea}$ & $0.0 \mathrm{Ea}$ & $0.0 \mathrm{Ea}$ & $0.0 \mathrm{~ns}$ \\
\hline Control & $1.4 \mathrm{Aa}$ & $0.9 \mathrm{Abc}$ & $1.0 \mathrm{Abc}$ & $1.2 \mathrm{Ab}$ & $1.2 \mathrm{Ab}$ & $28.2^{* *}$ \\
\hline $\mathrm{F}$ & $110.35 * *$ & $57.32 * *$ & $52.83^{* *}$ & $74.10 * *$ & $68.27 * *$ & ----- \\
\hline
\end{tabular}

probability, $\mathrm{ns}=$ non-significant. $\mathrm{F}$ (cultivars $\mathrm{x}$ herbicides $)=15.10^{* *} ; \mathrm{CV}(\%)=15.07$. 
Table 7. Result of the chemical analysis of the soil used as substratum.

\begin{tabular}{|c|c|c|c|c|c|c|c|c|c|}
\hline $\mathrm{pH}$ & O.M. & P. resin & $\mathrm{K}$ & $\mathrm{Ca}$ & $\mathrm{Mg}$ & $\mathrm{H}+\mathrm{Al}$ & SB & $\mathrm{T}$ & V \\
\hline $\mathrm{CaCl}_{2}$ & $\mathrm{~g} \mathrm{dm}^{-3}$ & $\mathrm{mg} \mathrm{dm}^{-3}$ & \multicolumn{6}{|c|}{$\mathrm{mmol}_{\mathrm{c}} \mathrm{dm}^{-3}$} & $\%$ \\
\hline 5.6 & 13 & 34 & 1.8 & 24 & 6 & 15 & 31.8 & 46.8 & 68 \\
\hline
\end{tabular}

Table 8. Herbicides and doses applied in pre-emergence, composing the chemical treatments.

\begin{tabular}{llll}
\hline Treatments & Active Ingredient & $\begin{array}{c}\text { Doses } \\
\text { (c.p. ha-1) }\end{array}$ & $\begin{array}{c}\text { Dosages } \\
\left.(\mathrm{kg} \mathrm{ha})^{-1}\right)\end{array}$ \\
\hline 1 & $2,4-D$ & $1.50 \mathrm{~L}$ & 1.209 a.e. \\
2 & Sulfentrazone & $1.20 \mathrm{~L}$ & 0.600 a.i. \\
3 & Hexazinone & $2.50 \mathrm{~kg}$ & 1.875 a.i. \\
4 & Clomazone & $2.00 \mathrm{~L}$ & 0.720 a.i. \\
5 & Mesotrione & $0.30 \mathrm{~L}$ & 0.144 a.i. \\
6 & Saflufenacil & $0.75 \mathrm{~g}$ & 0.525 a.i. \\
7 & Tebuthiuron & $2.00 \mathrm{~L}$ & 1.000 a.i. \\
8 & Imazapic & $175 \mathrm{~g}$ & 0.122 a.i. \\
9 & S-metolachlor & $1.75 \mathrm{~L}$ & 1.680 a.i. \\
10 & Amicarbazone & $2.0 \mathrm{~kg}$ & 1.400 a.i. \\
11 & Control plot (Water) & -- & - \\
\hline
\end{tabular}

metolachlor, mesotrione and imazapic) caused symptoms classified as low (Table 4).

Clomazone and mesotrione, although acting as inhibitors of carotenoid biosynthesis, caused controversial responses in the cultivars studied. Line 870 and cultivar IAC 503 were the most tolerant to mesotrione. On the other hand, no genotype showed tolerance to clomazone. The recommendation for mesotrione is pre-emergence application on dicotyledons such as potato and cassava, and post-emergence application on cotton. Clomazone, in turn, should be used in the pre-emergence of soy, cassava, bell pepper and cotton (Rodrigues and Almeida, 2011).

Studies on the possible effects of both products in the preemergence of peanuts are scarce. Furthermore, research on the effects of mesotrione indicates that mass and yield of soy in the pre-emergence were not reduced (Riddle et al., 2013a); while beans had total mass and yield reduced (Felix et al., 2007; Riddle et al., 2013b). Some studies show the application of clomazone in the pre-emergence of 'Jalo Precoce' beans (Fernandes et al., 2011) and castor beans (cultivars Íris and AL Guarany) (Maciel et al., 2007) was selective to crops.

\section{Dry matter of shoots and roots}

Analyzing the treatments of each cultivar for dry matter of shoots, 2,4-D, mesotrione and imazapic did not interfere with dry matter production of IAC Tatu-ST compared to the control plot. However, saflufenacil, s-metolachlor, clomazone and sulfentrazone reduced production by 27,36 , 45 and 64\%, respectively (Table 5).

Regarding the dry matter of roots of IAC Tatu-ST, treatments using 2,4-D and imazapic showed results similar to the control. The other products (saflufenacil, S-metolachlor, mesotrione, clomazone and sulfentrazone) have highly reduced the dry matter of roots: reduction of $36,43,50,64$ and $71 \%$, respectively (Table 6 ). The dry matter values relate to phytotoxicity levels, being noticed that even low and very low levels have impaired dry matter accumulation. As for line 870, treatments with 2,4-D, mesotrione, saflufenacil and imazapic provided shoot dry matter production similar to the control plot. Nonetheless, treatments with sulfentrazone, clomazone, and Smetolachlor caused reduction of $33 \%$. Regarding root dry matter, differently from 2,4-D, mesotrione, and imazapic (results similar to control), the saflufenacil negatively affected root development causing $22 \%$ reduction, which is similar to the treatments using sulfentrazone, clomazone and S-metolachlor that caused $33 \%$ reduction.

Data on shoot dry matter for IAC 505 show treatments using sulfentrazone, saflufenacil, and imazapic were similar to the control plot. However, sulfentrazone and imazapic have reduced the dry matter by 20 and $16 \%$, respectively. The remaining products, clomazone, S-metolachlor, mesotrione and 2,4-D have reduced the dry matter by 30, 30, 40 and $50 \%$, respectively. As for root dry matter, saflufenacil and imazapic were the only herbicides to promote values similar to the control plot. The remaining herbicides, sulfentrazone, clomazone and S-metolachlor, caused 30\% reduction, whereas mesotrione and 2,4-D caused 40 and $50 \%$ reduction, respectively (Table 6 ).

By analyzing the cultivar IAC 503, one notes that herbicides have acted similarly on shoot and root dry matter. Among the treatments, 2,4-D, mesotrione, and imazapic resulted in similar development (shoots and roots) to the control plot; but it is worth emphasizing that 2,4-D reduced shoot dry matter by $16 \%$. The other treatments, saflufenacil, sulfentrazone, clomazone and S-metolachlor caused reduction in plant growth. Shoot dry matter was reduced by $30,30,40$ and $40 \%$, respectively. For root dry matter, reduction caused by the four herbicides was $28 \%$.

Regarding cultivar Granoleico, herbicides also showed similar behavior for shoots and roots. Herbicides sulfentrazone and imazapic reduced plant dry matter (shoots and roots) by around 43\%. S-metolachlor, saflufenacil, and 2,4-D also impaired plant growth. Regarding shoots, reduction reached 25,42 and $42 \%$, respectively. For roots, reductions were about 33, 42 and $67 \%$ (S-metolachlor, saflufenacil and sulfentrazone). Only clomazone and mesotrione showed results similar to the control plot. However, the clomazone caused the most severe phytointoxication symptoms leading to reduced plant 
structure. Some studies have shown pre-emergence application of imazapic in peanuts have caused phytotoxicity and dry matter reduction in cultivars 'Tatu Vermelho' and 'IAC-5' 1,0 (doses of 0.98 and 140 g.ha-1) (Azania et al., 2004). In addition, yield losses of up to $25 \%$ (Runner IAC 886) were verified at the dose of $0.098 \mathrm{~kg}$ a.i. ha ${ }^{-1}$ (Luvezuti et al., 2014). In this study, imazapic also reduced the dry matter of some genotypes including 'IAC 505' and 'Granoleico'. However, even if there was no dry matter reduction in the other cultivars, the treatment has severely reduced their emergence. Few are the essays showing the effect of auxin herbicides on peanut crops. Most of these studies only relate the effect of post-emergence application for 2,4-D (Banks et al., 1977; Leon et al., 2014), although effects of its pre-emergence application are also little known. Prostko et al. (2003) state that the application of 2,4-D $(0.6$ and $0.75 \mathrm{~kg}$ a.i. ha-1) on a cultivar must be evaluated 7 days after planting. In this work, 2,4-D reduced only the development of cultivars IAC 505 and Granoleico. Nevertheless, even if not causing phytotoxicity symptoms in any genotype, the herbicide reduced the emergence of all studied cultivars.

Regarding the effects of PROTOX-inhibitor herbicides (saflufenacil and sulfentrazone), overall all cultivars were sensitive to herbicide application, given their reduced emergence and/or development. Studies on saflufenacil application showed pre-emergence application with 12, 25 and $50 \mathrm{~g} \mathrm{ha}^{-1}$ caused no injuries and or growth reduction of peanut cultivar 'Georgia Green' (Morichetti et al., 2012). Preemergence application of saflufenacil $\left(100 \mathrm{~g} \mathrm{ha}^{-1}\right)$ in soybean crop did not cause injuries nor affected yield, but its application in other dicotyledons, such as white bean, have damaged plants (Soltani et al., 2010). Some studies found in the literature report pre-emergence application of sulfentrazone in peanut crop reduced its development by $80 \%\left(0.06 ; 0.11 ; 0.17 ; 0.22 \mathrm{~kg} \mathrm{ha}^{-1}\right.$ ) (Grichar et al., 2006), and up to $96 \%\left(0.25 ; 0.31\right.$ and $0.37 \mathrm{lb}$ a.i. $\left.\mathrm{A}^{-1}\right)$ (Grichar, 2006). Notwithstanding, research conducted by Grey et al. (2000) show seven cultivars studied were tolerant to preemergence application of sulfentrazone $(0.14 ; 0.21 ; 0.28$; 0.35 and $0.42 \mathrm{~kg}$ a.i. ha- ${ }^{-1}$ ). It is noteworthy that the crop's tolerance to sulfentrazone may depend on dosage, application time, cultivar used, soil type and $\mathrm{pH}$ (Johnson III and Mullinix Jr, 2005). Peanut sown in sandy loam soil was tolerant to sulfentrazone (Grey et al., 2000), but the same crop was severely impaired when sown in sandy Acrisol (Johnson and Mullinix, 1994). In this study, herbicide Smetolachlor reduced the total dry matter of all cultivars. However, some studies report tolerance and yield increases of 'Florunner', GK-7, AT $120\left(1.1 ; 1.5\right.$ and $\left.2.2 \mathrm{~kg} \mathrm{ha}^{-1}\right)$ (Grichar et al., 2001), and cultivars 'NC 10 C', 'NC 7' and 'NCV $11^{\prime}$ (1.42 kg a.i. ha ${ }^{-1}$ ) (Ducar-Tredaway et al., 2006). The crop tolerance to herbicides depends on many factors including the dose and physicochemical characteristics of the product, herbicide positioning along the soil profile, use of adjuvants, plant growth stage, soil characteristics and climate conditions before and after application (Rodrigues and Almeida, 2011).

\section{Materials and Methods}

\section{Study area and plant material}

The experiment was conducted in January 2015, city of Jaboticabal - SP under the coordinates $21^{\circ} 14^{\prime} 05^{\prime \prime} \mathrm{S}$ and $48^{\circ} 17^{\prime} 09^{\prime \prime}$ W and $615 \mathrm{~m}$ of altitude. According to the Köppen climate classification, it is Cwa subtropical climate with dry winters and rainy summers.

We used seeds of five genotypes (cultivars: IAC 503, IAC 505, IAC Tatu-ST, Granoleico; and line: L.870). Cultivars IAC 503 and IAC 505, belonging to the Virginia group, have fast growth habit and moderate resistance to foliar diseases [late leaf spot caused by Cercosporidium personatum (Berk. \& Curt.) Deighton; early leaf spot caused by Cercospora arachidicola Hori; and rust, caused by Puccinia arachidis Speg]. Their yield potential reaches $6,000 \mathrm{~kg} \mathrm{ha}^{-1}$ with indeterminate growth habit and, cycle between 130 and 140 days, which can be extended depending on the soil and climatic conditions. Both cultivars have seeds with about $50 \%$ oil and between $70 \%$ to $80 \%$ oleic acid contents, having good acceptability in the national market (Godoy et al., 2009). Line L.870 was also used, which has fast growth habit and high yield potential. Nonetheless, this material is being improved and is still not available for commercialization. Furthermore, cultivar IAC Tatu-ST was evaluated: upright growth habit and greater earliness (cycle between 90 and 100 days). Belonging to the group Valencia, this cultivar is the favorite of Brazilian consumers, especially for showing elongated pods with 3 to 4 red grains; slightly sweet taste and yield potential of $4000 \mathrm{~kg} \mathrm{ha}^{-1}$ (Castro et al., 2011; Godoy et al., 2003; Godoy et al., 1996).

In addition to the materials developed by the Agronomic Institute of Campinas (IAC), this study also evaluated the cultivar Granoleico with increasing growth in planting areas. The company Criadero El Carmem ${ }^{\circledR}$ developed this cultivar in Argentina. It also has fast growth habit, longer cycle (about 157 days), high oleic acid content and estimated yield of $3,000 \mathrm{~kg} \mathrm{ha}^{-1}$ (Soave et al., 2004).

\section{Pot capacity and soil analysis}

Sowing was performed in $2.5 \mathrm{~L}$ pots filled with substratum consisting of sand and earth $(2: 1 \mathrm{v} / \mathrm{v})$. One cultivar was sown per pot, using 15 seeds in $3 \mathrm{~cm}$ deep holes. Seeds were previously treated with insecticide thiamethoxam and fungicide carboxin + thiram. Insecticide (thiamethoxam, 200 $\mathrm{mL} \mathrm{ha} \mathrm{a}^{-1}$ ) and fungicide (pyraclostrobin, $600 \mathrm{~mL}$ ha-1) applications were performed as preventive control against insect attacks and diseases at 35 days after sowing (DAS) and weekly thereafter during all the experimental period. The earth part used was a medium texture Oxisol. The chemical analysis of the substratum is shown in Table 7.

\section{Treatments}

The experiment was a random block design in $11 \times 5$ factorial arrangement, whose treatments were 10 herbicides applied in pre-emergence, a control plot (with no chemical treatment) and five peanut genotypes (IAC Tatu-ST, line 870, IAC 505, IAC 503 and Granoleico), in four replications. Data on chemical treatments are shown in Table 8 with doses being used to simulate the worst residual effect situation (doses used for sugarcane crops).

\section{Herbicide application}

Herbicide application was performed in pre-emergence using a $\mathrm{CO}_{2}$-pressurized backpack sprayer equipped with 
four TTJ60-11002 VP nozzles. The equipment was regulated at 2.2 bar pressure for the equivalent of a $200 \mathrm{~L} \mathrm{ha}^{-1}$ distribution rate. The temperature $\left(33^{\circ} \mathrm{C}\right)$ and relative humidity (68\%) were recorded at the application.

\section{Measured variables}

The counting of emerged seedlings was performed daily up to 15 days after application (DAA) for emergence rate. Visual evaluations of phytotoxicity were performed at 16, 23 and 30 DAA using the scale given by the European Weed Research Council (EWRC, 1964). This scale classifies phytotoxicity as 1: absence of symptoms; 2: very mild symptom; 3: mild symptom; 4: moderate symptom; 5 : medium symptom; 6: almost strong symptom; 7: strong symptom; 8: very strong symptom; 9: plant death. At the end of the experiment (30 DAA), dry matter of shoots and roots was obtained by drying the material in air-circulation oven at $65^{\circ} \mathrm{C}$ for 76 hours.

\section{Statistical analysis}

Data were subjected to analysis of variance by the $F$ test ( $p \leq 0.01$ and $\leq 0.05$ ) and means were compared by the Tukey test $(p \leq 0.05)$. Statistical analysis was performed using the AgroEstat software (Barbosa and Maldonado Júnior, 2015).

\section{Conclusion}

From the foregoing in this study, we conclude line 870 and cultivar IAC 503 were tolerant to mesotrione applied in preemergence. Moreover, the pre-emergence application of herbicides hexazinone, tebuthiuron and amicarbazone caused death of all genotypes. Sulfentrazone and clomazone caused strong visual symptoms of toxicity and impaired the emergence and development of all genotypes. Imazapic, 2,4$D$, saflufenacil, and S-metolachlor, in turn, caused mild visual symptoms of toxicity, but negatively affected the emergence and development of all genotypes. Depending on the product, the residual effects of herbicides from sugarcane crops on peanut genotypes in succession can cause serious damages. The genotypes do not react equally to the products; thus, there being a need for further studies under field conditions to confirm the responses obtained in this study and to verify whether the yield potential is affected.

\section{Acknowledgements}

The authors thank the National Council for Scientific and Technological Development (Conselho Nacional de Desenvolvimento Científico e Tecnológico - $\mathrm{CNPq}$ ), process No. 142462/2013-6 and 311281/2013-3.

\section{References}

Agostinho FH, Gravena R, Alves PLCA, Salgado TP, Mattos ED (2006) The effect of cultivar on critical periods of weed control in peanuts. Peanut Sci. 33: 29-35.

Agrofit. Sistemas de Agrotóxicos Fitossanitários (2018). Ingredientes ativos: herbicidas. Available: http://agrofit.agricultura.gov.br/agrofit_cons/pr incipal_agrofit_cons. Access: September 16, 2018.
Armel GR, Rardon PL, Comrick MC, Ferry NM (2007) Differential response of several carotenoid biosynthesis inhibitors in. mixtures with atrazine. Weed Technol. 21:947-953.

Azania CAM, Azania AAPM, Centurion MAPC, Alves PLCA (2004) Seletividade do imazapic para dois cultivares de amendoim (Arachis hypogaea) cultivados na ausência e na presença de palha de cana-de-açúcar. Planta Daninha. 22:145-150.

Balota EL, Kanashiro M, Colozzi-Filho A, Andrade DS, Dick RP (2004) Soil enzyme activities under long-term tillage and crop rotation systems in subtropical agro-ecosystems. Braz J Microbiol. 35:300-306.

Banks PA, Kirby MA, Santelmann PW (1977) Influence of postemergence and subsurface layered herbicides on horsenettle and peanuts. Weed Sci. 25:5-8.

Barbosa JC, Maldonado Júnior W (2015) Experimentação agronômica e AgroEstat: sistema para análises estatísticas de ensaios agronômicos. Jaboticabal, SP: Multipress, 396 p.

Burke IC, Schroeder M, Thomas WE, Wilcut JW (2007). Palmer amaranth interference and seed production in peanut. Weed Technology, 21:367-371.

Castro RSD, De Sá ME, Daiuto ÉR, Castro GR (2011) Avaliação sensorial dos grãos de três cultivares de amendoim torrado por um período de doze meses armazenamento. Global Sci. Technol. 4:11-20.

CONAB. Companhia Nacional de Abastecimento (2018) Grãos. Acompanhamento da Safra Brasileira de Grãos. Available: http://www.conab.gov.br/. Access: September 16, 2018

Ducar-Tredaway JA, Wilcut JW, Jordan DL, Faircloth J, Swann CW (2006) Evaluation of diclosulam and S-metolachlor applied preplant incorporated in peanut (Arachis hypogaea). Peanut Sci. 33:137-141.

EWRC. European Weed Research Council. Report of the 3rd and 4rd meetings of EWRC. Committees of Methods in Weed Research. Weed Res. 1964.

Felix J, Doohan DJ, Bruins D (2007) Differential vegetable crop responses to mesotrione soil residues a year after application. Crop Prot. 26:1395-1403.

Fernandes CPC, Braz AJBP, Procópio SO, Dan HA, Braz GBP, Barroso ALL, Menezes CCE, Simon GA, Braz LBP (2011) Tolerância do feijoeiro a herbicidas aplicados na cultura da cana-de-açúcar. Rev. Bras. Herbic. 10:121-133.

Godoy IJ, Carvalho CL, Martins ALM, Bolonhezi D, Freitas RS, Kasai FS, Ticelli M, Santos JF, Oliveira EJ andMorais LK (2009) IAC 503 e IAC 505: cultivares de amendoim com a característica alto oleico. In Anais do 5o congresso brasileiro de melhoramento de plantas. SBMP, Guarapari (CD-ROM).

Godoy ID, Moraes SA, Kasai FS, Martins ALM, Pereira JCVNA, Moraes, ARA, Teixeira, JPF (2003) Cultivares de amendoim IAC: novas opções para o mercado de confeitaria. Campinas: Instituto Agronômico.

Godoy IJ, Razera LF, Ticelli M, Martins ALM, Pereira JCVNA (1996) Efeito do tamanho e origem das sementes de amendoim, cultivar Tatu, na produtividade e características das sementes produzidas. Rev. Bras. Sementes. 18:77-82.

Grey TL, Bridges DC, Brecke BJ (2000) Response of seven peanut (Arachis hypogaea) cultivars to sulfentrazone. Weed Technol. 14:51-56. 
Grichar WJ, Besler BA, Dotray PA (2006). Weed control and peanut (Arachis hypogaea) response to sulfentrazone. Crop Prot. 25:753-757.

Grichar WJ, Lemon RG, Brewer KD, Minton BW (2001) SMetolachlor compared with metolachlor on yellow nutsedge (Cyperus esculentus) and peanut (Arachis hypogaea). Weed Technol. 15:107-111.

Heap, I (2018) The International Survey of Herbicide Resistant Weeds. Online. Internet. Tuesday, October 9. Available: www.weedscience.org.

Johnson III WC, Mullinix Jr, B. G (1994) Use of F6285 for weed control in peanut: efficacy and crop injury. Peanut Sci. 21:65-68.

Johnson III WC, Mullinix Jr. B.G (2005) Effect of herbicide application method on weed management and crop injury in transplanted cantaloupe production. Weed Technol. 19:108-112.

Leon RG, Ferrell JA, Brecke BJ (2014) Impact of exposure to 2,4-D and dicamba on peanut injury and yield. Weed Technol. 28:465-470.

Luvezuti RA, Bacha AL, Alves PLCA, Pavani MCMD, Nepomuceno MP (2014) Eficácia de herbicidas no controle de plantas daninhas e seletividade na cultura do amendoim Runner IAC 886. Rev. Bras. Herbic. 13:207-215.

Maciel CDG, Poletine JP, Velini ED, Zanotto MD, Amaral JGC, Santos HR, Artioli JC, Silva TRM, Ferreira RV, Lolli J, Raimondi, MA (2007) Seletividade de herbicidas em cultivares de mamona. Rev. Bras. Ol. Fibros. 11:47-54.

MAPA (Ministério da Agricultura, Pecuária e Abastecimento) (2015) Cultura com Suporte Fitossanitário Insuficiente. Registro de agrotóxicos para culturas com suporte fitossanitário insuficiente. Manual de procedimentos (Instrução Normativa Conjunta 01, p. 24). Retrieved September 8 , from http://www.agricultura.gov.br/assuntos/insumosagropecuarios/insumos-agricolas/agrotoxicos/culturascom-suporte-fitossanitario-insuficiente-csfi.

Marenco RA, Santos AMB (1999) Crop rotation reduces weed competition and increases chlorophyll concentration and yield of rice. Pesq. Agropec. Bras. 34:1881-1887.

Mithila J, Hall JC, Johnson WG, Kelley KB, Riechers DE (2011) Evolution of resistance to auxinic herbicides: historical perspectives, mechanisms of resistance, and implications for broadleaf weed management in agronomic crops. Weed Sci. 54:445-457.

Morichetti S, Ferrell J, MacDonald G, Sellers B, Rowland D (2012) Weed management and peanut response from applications of saflufenacil. Weed Technol. 26:261-266.
Nepomuceno MP, Alves PLCA, Dias TCS, Cardozo NP, Pavani MCMD (2007) Efeito da época de semeadura nas relações de interferência entre uma comunidade infestante e a cultura do amendoim. Planta Daninha. 25:481-488.

Prostko KP, Crey TL, Johnson III WC, Grichar WJ, Besler BA, Brewer KD, Eastin EF (2003) Influence of preplant applications of 2,4-d, dicamba, tribenuron, and tribenuron plus thifensulfuron on peanut. Peanut Sci. 30:18-22.

Riddle RN, O'Sullivan J, Swanton CJ, Acker RCV (2013a) Crop response to carryover of mesotrione residues in the field. Weed Technol. 27:92-100.

Riddle RN, O'Sullivan J, Swanton CJ, Acker RCV (2013b) Field and greenhouse bioassays to determine mesotrione residues in soil. Weed Technol. 27:565-572.

Rodrigues BN, Almeida FS (2011) Guia de herbicidas. 6 ed. Londrina, PR: Edição dos autores, 697 p.

Santos RC, Freire RMM, Lima LM, Zagonel GF, Costa BJ (2012) Produtividade de grãos e óleo de genótipos de amendoim para o mercado oleoquímico. Cienc Agron. 43:72-77.

Shoup DE, Al-Khatib K (2004) Control of protoporphyrinogen oxidase inhibitor-resistant common waterhemp (Amaranthus rudis) in corn and soybean. Weed Technol. 18:332-340.

Soave JH, Bianco CA, Kraus TA (2004) Description of two new cultivars of Peanut Arachis hypogaea subsp. hypogaea var. hypogaea. Agriscientia. 21:85-88.

Soltani N, Shropshire C, Sikkema PH (2010) Sensitivity of leguminous crops to saflufenacil. Weed Technol. 24:143146.

Tan S, Evans RR, Dahmer ML, Singh BK, Shaner DL (2005) Imidazolinone-tolerant crops: history, current status and future. Pest Manag Sci. 61:246-257.

Unica. União da Indústria de Cana-de-Açúcar (2018) Produção: Área cultivada com cana-de-açúcar mapeamento de área centro-sul. Available: http://www.unicadata.com.br. Access: September 16, 2018.

Ventrella A, Catucci L, Agostiano A (2010) Herbicides affect fluorescence and electron transfer activity of spinach chloroplasts, thylakoid membranes and isolated Photosystem II. Bioelectrochemistry. 79:43-49.

Zanardo HG, Carrega WC, Hijano N, Cesarin AE, Martins PFRB, Godoy IJ, Alves PLCA (2018) Herbicide selectivity in peanut cultivars. Journal of Agricultural Science. 10:447456. 